\title{
Select Bibliography of Higher Education in Canada Bibliographie choisie sur l'Enseignement supérieur au Canada
}

\author{
ROBIN S. HARRIS, MARCEL de GRANDPRE, JANE ROSENBAUM*
}

This bibliography follows the one pubCette bibliographie continue celle qui a lished in Stoa, Vol. III, no 2, 1973, pp. 175-82. All references are shown as in Robin S. Harris, A Bibliography of Higher Education in Canada, Supplement 1971, University of Toronto Press, Les Presses de l'Université Laval, 1971.

paru dans Stoa, Vol. III, no 2, 1973, pp. 175-82. Les references sont données comme dans Robin S. Harris, Bibliographie de l'enseignement supérieur au Canada, Supplement 1971, University of Toronto Press, Les Presses de l'Université Laval, 1971.

\section{1 - DEGREE-GRANTING UNIVERSITIES AND COLLEGES UNIVERSITES ET COLLEGES QUI CONFERENT DES GRADES}

1 History and Organization / Histoire et organisation

A General/Généralités

Canada, Statistics Canada, Education, Science and Culture Division. Education in Canada: a Statistical Review for the Period 1960-61 to 1970-71. Ottawa: Information Canada, 1973. Pp. 613.

Hunt, P. "Commentary: Toward the Totalitarian University," Jour. Can. Studies VIII, 1 (February, 1973), 57-64.

Wilson, D.N. "University of Canada North: Promise for an Alternative University Structure," Can. Inter. Ed. II, 1 (June, 1973), 3-14.

B The Universities of New Brunswick

La Commission de Planification Académique de l'Université de Moncton. Rapport. Moncton: l'Université de Moncton, 1971. Pp. 624.

\footnotetext{
* Robin S. Harris is Professor of Higher Education, University of Toronto.

Marcel de Grandpré est Directeur de la Section d'Education Comparée et des Fondements de l'Education, Faculté des Sciences de l'Education, Université de Montréal.

Jane Rosenbaum is Head Librarian, Association of Universities and Colleges of Canada.
} 
C Les Universités du Québec

Crépeau, J.-C. "A l'Université de Montréal: planification oui . . mais," Educ. Québec I, 12 (mars 1971), 13-17.

Conseil des Universités. Objectifs généraux de l'enseignement supérieur et grandes orientations des établissements. Québec: Le Conseil, 1972/1973. 3 vols.

1 L'évolution récente de l'cnseignement supérieur au Québec. Pp. 253.

2 Objectifs généraux de l'enseignement supérieur. Pp. 227.

3 Les orientations de l'enseignement supérieur dans les années '70. Pp. 392.

Dumouchel, E. "L'ancienne et la nouvelle chartes de l'Université Laval," Revue de l'AUPELF, $\mathrm{X}, 1$ (juin 1972), 15-19.

Joncas, J. "L'enseignement coopératif à l'Université de Sherbrooke,"Act. Péd. 24 (juin 1972). 5-19.

Magnuson, R. "Education and Society in Quebec in the 1970's," Jour. Ed. Thought VII, 2 (November 1973), 94-104.

Pardoen, A. "Université de Sherbrooke: échanger un peu de liberté contre un peu de securité," Educ. Québec I 14 (avril 1971), 7-9.

Whitelaw J. "The Universities of Quebec-Guidelines for the 1970's," Univ. Affairs XIII (November 1972), 12-13.

\section{The Universities of Ontario}

Adelman, H. Re-building the University: the Holiversity. Toronto: New Press, 1973. Pp. 152.

Anisef, P. and Jansen C., York Graduate Study. Toronto: Institute for Behavioral Research, York University, 1972. 7 vols.

1 Background Characteristics.

2 The Honours and Ordinary Programme.

3 Atkinson and York Graduates.

4 Decisions about University, Major, Career.

5 The York Experience.

6 Present Work Experiences.

7 Experiences of those Presently in Graduate School.

Gidney, R.D. "Centralization and Education: the Origins of an Ontario Tradition," Jour. Can. Studies VII, 4 (November, 1972), 33-48.

Jansen, C. Housing, Transport and Social Participation. Toronto: Institute for Behavioral Research, York University, 1972. 2 vols.

1 The University Setting. Pp. 67.

2 A Survey of Undergraduates. Pp. 200.

Sheffield, E.F., ed. Agencies for Higher Education in Ontario. Toronto: Ontario Institute for Studies in Education, 1974. Pp. 82.

Sheffield, E.F. "The Learning Society: an Overstatement," Queen's Q. LXXX, 3 (Autumn 1973), 434-49.

University of Ottawa, Commission on the Revision of Teaching and Research Structures. The University of Ottawa, What is it? Ottawa: University of Ottawa, 1973. 10 vols.

1 La structure des unités d'enseignement et de recherche. Pp. 29. / The structure of teaching and research units. Pp. 27.

2 Programmes d'études de baccalauréat et d'année pré-universitaire. Pp. 70. / Academic programs at the baccalaureate and pre-university levels. Pp. 66.

3 Les programmes d'études à temps partiel. Pp. 19./ Part-time programs. Pp. 18.

4 I: Les programmes d'études supérieures, II: Les programmes d'études professionelles, III: Les sciences de la santé. Pp. 27. / I: Graduate programs, II: Professional programs, III: Health Sciences. Pp. 24.

5 La clientèle étudiante à temps complet. Pp. 35./ Full-time student population. Pp. 33.

6 Le corps professoral. Pp. 44. / The teaching staff. Pp. 41. 
7 Mission impossible. Pp. 19. / Mission impossible. Pp. 17.

8 La recherche. Pp. 23. / Research. Pp. 21.

9 Les services. Pp. 20./ Services. Pp. 20.

10 Le gouvernement de l'université. Pp. 60. / The government of the university. Pp. 60. Weinzweig, P. "The Open University: Technologically Assisted Living and Learning in the University of Ontario," OCUFA Newsletter V, 4 (April 1972), 5-6.

\section{E The Universities of Manitoba}

Morgan, J., ed. Report of the Task Force on Post-Secondary Education in Manitoba. Winnipeg: Queen's Printer, 1973. Pp. 228.

\section{$G$ The Universities of Alberta}

Zachariah, M. "Is there a Plan in a Choice of Futures?" Jour. Ed. Thought VII, 2 (August 1973), 121-27.

\section{Current Trends and Problems / Oriéntation et problèmes présents}

\section{A General/Généralités}

Black, E. "A Perspective on the "Crisis" in Post-Secondary Education," CAUT Bull. XXI, 4 (March, 1973), 16-20.

Gill, A. "The Current Situation and How it Came to Pass," Univ. Affairs XIV, 1 (January, 1973), $1-6$.

Porter, M.R., J. Porter and B. Blishen. Does Money Matter? Prospects for Higher Education. Toronto: Institute for Behavioral Research, York University, 1973. Pp. 318.

Ross, M. "The University - Now and Tomorrow: Rule by Computer?" Univ. Affairs XIII, 3 (March, 1972), 2-3.

\section{B University Government / Administration universitaire}

Brown, J. "One Tier or Two Tier Government: University of Waterloo's Answer," Can. Assoc. Univ. Development Officers Development Journal III, 2 (December, 1972), 3-4.

Daly, T. "The New Governing Council of the University of Toronto," CAUDO Development Journal III, 1 (October, 1972), 3-4.

Flower, G. "Promising Design or Potential Disaster? It Depends on Where You Sit," $E d$. Conada XIII, 3 (September, 1973), 33-40.

Smith, W.A.S. "A Presidency in Retrospect," Univ. Affairs XIII, 8 (October, 1972), 2-3.

C University Finance / Finances universitaires

Hartle, D.G. "The Financing of Higher Education in the '70's: a Viewpoint from Ottawa," Stoa III, 2 (1973), 1 1540.

Macdonald, J.B. "Financing of Research in Universitics," Stoa III, 2 (1973), 157-74.

Oliver, M. "Factors Reshaping the Financing of Higher Education in the 1970's," Stoa III, 2 (1973), 105-11.

Ontario Confederation of Universtiy Faculty Associations. "Brief on the Federal Role in University Finance," OCUFA Newsletter VII, 1 (September 1973), 17.

Parr, J.G. "A Little Less of the 'Who Pays?' . . . a Little More of the 'What For?" Stoa III, 1 (1973), 141-49.

Proulx, P.-P. "Réflexions sur les facteurs déterminants de l'évolution du financement de l'enseignement supérieur au Canada dans les années 1970 et 1980," Stoa III, 1 (1973), $151-56$

Stager, D.A.A. "Federal Government Grants to Canadian Universities, 1951-66," Can. Hist. Rev. LIV, 3 (September 1973), 287-97. 
D The University and the State / L'Université et l'Etat

Hayes, F.R. The Chaining of Prometheus: the Evolution of a Power Structure for Canadian Science. Toronto: U. of T. Press, 1974. Pp. 217.

Holland, J.W. "A Reappearance of National and Provincial Educational Policy Styles," Can. Inter. Ed. II, 1 (June 1973), 47-66.

Macdonald, J.B. "Change and the Universities: University-Government Relations," Can. Public Admin. XIII, 1, (1970), 7-18.

"Policies for Science and the Universities," (interview with Alastair Gillespie) Univ. Affairs XIII, 6 (June-July, 1972), 2-4.

$\mathrm{G}$ University Planning / La planification universitaire

Macdonald, J.B. "Health and Good Estate," Can. Jour. Public Health LXII, (May-June 1971), 185-91.

Pardoen, A. "Pourquoi planifier," Educ. Québec I, 12 (mars 1971), 6-7.

Pelletier, D. "Planification: l'initiative aux universités," Educ, Québec I, 14 (avril 1971), 1013.

\section{Curriculum and Teaching / Programme d'édudes et méthodes}

A General/Généralités

Duval, R. "La pédagogie universitaire, un problème de relations humaines," Act. Péd. 25 (août 1972), 11-46.

Lemire, V. "Le micro-enseignement: un bilan provisoire," Prospectives VIII, 3 (mai 1972), 203-05.

C The Humanities/Les Humanités

Bernard, J.-P. "Quelques interrogations sur la formation des professeurs d'histoire," Cahiers Univ. Québec 25 (1970), 161-66.

Eid, N.F. "Pour une méthodologie plus exigeante de l'apprentissage en histoire," Cahiers Univ. Québec 25 (1970), 155-59.

"French Departments Mostly Ignore French-Canadian Studies Survey Shows," Univ. Affairs XIII, 10 (December 1972), 9.

Lower, A.R.M. "That Humble Fellow, the Historian - Some Reflections on Writing History," Jour. Can. Studies VII, 1 (February 1972), 45-50.

Vidal, F. "What Has Happened to Foreign Language Instruction?" Univ. Affairs XIV, 10 (December 1973), 7.

\section{Social Sciences / Sciences sociales}

Cole, D. "The Origins of Canadian Anthropology," Jour. Can. Studies VIII, 1 (February 1973), 34-45.

Gurstein, M. "Towards the Nationalization of Canadian Sociology," Jour. Can. Studies VII, 3 (August 1972), 50-58.

Lambert, R.D. and J. Curtis. "Nationality and Professional Activity Correlates among Social Scientists: Data Bearing on Conventional Wisdoms," Can. Rev. Soc. Anthrop. X, 1 (February 1973), 62-80.

Sullivan, S.M. "Psychology and Teaching," Can. Jour. Behav. Science VI, 1 (January 1974), $1-29$.

Warnock, J.W. "International Relations as a Canadian Academic Discipline," Jour. Can. Studies VIII, 1 (February 1973), 46-57. 


\section{F Professional Education / Enseignement professionel}

Beacock, E.S. "A View of Continuing Education of Librarians by an Employer," CACUL Newsletter IV, 6 (March 1973), 419-25.

Brunelle, J., et al. "Le micro-enseignement: un outil de formation des enseignants en éducation physique," Mouvement VII, 3 (septembre 1972), 143-51.

Cockshutt, M.E. "Education for librarianship: the View of the Library School," CACUL Newsletter IV, 6 (March, 1973), 426-35.

Coisman, N. "Enseignement professionel: enseignement dominé?" Prospectives IX, 5 (décembre, 1973), 274-83.

Denis, L.G. and L.J. Houser. "A Study of the Need for Ph.D.'s in Library Science in Large Canadian Universities," Can. Library Jour. XXIX, 1 (January-February, 1972), 19-27.

Fewster, J. "New Dimensions in International Home Economics Programs," Can. Home Econ. Jour. XXII, 3 (July, 1972), 3-10.

Hulse, J.H. "The Household Scientist in International Development," Can. Home Econ. Jour. XXIII, 2 (April, 1973), 3-16.

Lando, F. "Why Six Librarians Chose Other Careers," Can. Library Jour. XXX, 2 (MarchApril, 1973), 100-05.

Larivière, J. et C. Perron. "Quel marché attend les diplômés en administration," Commerce LXXIV, 1 (janvier 1972), 9-14; 2 (février 1972), 20-23; 3 (mars 1972), 40-44; 4 (avril 1972), 50-55.

McLeish, J.B. "Some Correlates of Political and Religious Beliefs in Student-Teachers," Alta. Jour. Ed. Res. XIX, 2 (June, 1973), 159-83.

McLeish, J.B. "Teacher Education: Environments and Outcome," Alta. Jour. Ed. Res. XIX, 1 (March, 1973), 66-81.

Martin, R.A. Future Directions for Teacher Education: a Delphi Survey Involving Education of Teachers and Recent Graduates of Teachers of a Program in Teacher Education. Toronto: Faculty of Education, Univ. of Toronto, 1974. Pp. 46.

Picot, D. "La formation pédagogique: théorie ou pratique?," Act. Péd. 18 (juin 1971), 48-55.

Queen's University, Kingston. Canadian Workshop Conference on the Economics of Medical Education 1973. Ottawa: Association of Canadian Medical Colleges, 1973. Pp. 141.

Simpson, E.C. "Home Economics-A Vital Force in the Life of the Individual," Can. Home Econ. Jour. XXIII, 3 (July 1973), 3-10.

Smitheran, V. et al., Committee on Teacher Education. Teacher Education: Perseverance or Professionalism. Charlottetown: University of Prince Edward Island, 1971. Pp. 133.

\section{G Graduate Studies}

Farine, A. "The Output of Canadian Universities as Measured by Graduate Degrees," Alta. Jour. Ed. Res. XIX, 2 (June 1973), 119-28.

$\mathrm{H}$ Adult and Continuing Education

Campbell, D.D. "Taking the Tide at the Flood; a Look at the Status of Continuing Education in Canada," Ed. Canada XIII, 3 (September 1973), 23-27.

Canada, Statistics Canada, Education, Science and Culture Division. Continuing Education, Part II, Post-Secondary Level, 1970-71. Ottawa: Information Canada, 1973. Pp. 45.

Gass, J.R. "L'education récurrente: une solution à la crise de l'enseignement," Commerce LXXV, 11 (novembre 1973), 50-56.

Vézina, C. "Plaidoyer pour une coordination de l'éducation des adultes," Prospectives IX, 1 (février, 1973), 24-30.

I Admissions

Nyberg, V.R. and R.G. Baril. "SACU Test Variables as Predictors of University GPA," Alta. Jour. Ed. Res. XIX, 4 (December 1973), 303-08. 
Pike, R. "Enrolment and Accessibility: Retrospect and Prospect," Univ. Affairs XIV, 9 (November 1973), 24.

\section{K Instructional Aids}

Canada, Statistics Canada, Education Division. Instructional Media in Universities of the Atlantic Provinces 1972. Ottawa: Information Canada, 1973. Pp. 37.

Doyle, W.G. "Multimediated Instruction in the Health Sciences," Jour. Ed. (N.S.) XXII, 1 (Summer 1972), 36-43.

\section{Canadian Studies / Etudes canadiennes}

Clarkson, S. "Lament for a Non-subject: Reflections on Teaching Canadian-American Relations," Inter. Jour. XXVII, 2 (Spring 1972), 265-75.

Gutteridge, D. "Teaching the Canadian Mythology: a Poet's View,"Jour. Can. Studies VIII, 1 (February 1973), 28-32.

Mathews, R.D. "U.S. Expansionism, Canadian Literature, and Canadian Intellectual History," Jour. Can. Studies VI, 4 (November 1971), 30-42.

Miles, E.J. "Canadian Studies in the United States: Challenge and Frustrations," Inter. Jour. XXVII, 2 (Spring 1972), 250-64.

Slater, D.W. "Canadian Studies and Canadian Faculty at Canadian Universities," Univ. Affairs XIII, 2 (February 1972), 6-7.

Waterman, A.M.C. "The Canadian Identity and Canadian Universities," Univ. Affairs XIV, 2 (February 1973), 2-3.

\section{Research and Scholarship / Recherche et études}

\section{A General/Généralités}

Jackson, R.W. "A New Model of the University: Not One Thing but Many," Science Forum VI, 4 (August 1973), 9-13.

Polanyi, J.C. "Rationalizing Research in the Universities: the Bonneau-Corry Report," CAUT Bull. XXI, 5 (April 1973), 10-13.

"Survey of Canadian University Practice with Respect to Faculty Offprints and University Publications," CACUL Newsletter V, 1 (September 1973), 7-11.

C In the Sciences

"NRC Grants and Scholarship - a Link Between University and Industry / Les subventions et Ies bourses du CNRC, lien entre les universités et l'industrie," Science Dimension V, 5 (October 1973), 16-23.

Paquet, J.-G. "Nos universités doivent planifier la recherche en génie," Science Forum VI, 4 (août 1973), 26-28.

"Quebec Universities Express Concern About Research Institute (INRS)," Univ. Affairs XIV, 4 (April 1973), 9.

Towell, M.E. "What Does Society Want of Us? A Summation of the Conference of MRC Scholars," Medical Research Council. Newsletter / Conseil de recherches médicales. Actualités II, 2 (January 1972), 8-10.

Tremblay, G.Y. "Le scientifique exige ...," Medical Research Council. Newsletter / Conseil de recherches médicales. Actualités II, 2 (January 1972), 8-10.

D In the Humanities and Social Sciences

Drummond, I. "Bonneau, Corry, and the Social Sciences: Is Planning Necessary?" CAUT Bull. XXI, 5 (April 1973), 14-15, 26. 
F Libraries / Bibliothèques

Pannu, G.S. "Research in Librarianship and the Canadian Library Association," Can. Library Jour. XXIX, 4 (July-August 1972), 300-05.

Rothstein, S. "From Reaction to Interaction: the Development of the North-American University Library," Can. Library Jour. XXIX, 2 (March-April 1972), 111-15.

Stienvalt, R. "A Cooperative Library System for the Ontario Universities," CACUL Newsletter V, 1 (September 1973), 3-6.

Webster, D. "Activities of the ARL Office of Management Studies," CACUL Newsletter IV, 3 (December, 1972), 24-37.

$\mathrm{H}$ Professional and Learned Societies / Sociétés savantes et professionnelles

Lang, M. and E. Upton, eds., The Dietetic Profession in Canada. Toronto: Canadian Dietetic Association, 1973. Pp. 98.

Maskow, M. "The Future of C.H.E.A.," Can. Home Econ. Jour. XXIII, 4 (October 1973), 3-9.

Wilson, J.T. "The Royal Society: Now a Revitalized National Academy," Science Forum VI, 5 (October 1973), 3-6.

Wilson, J.T. "The Scientific Societies: What Are They - and What Should They Become?" Science Forum VI, 2 (April 1973), 7-9.

\section{The Student and Student Services / L'Etudiant et les services aux étudiants}

\section{A General/Généralités}

Camp, D. "The Public Image of the University Student Today," AUCC Proc. 1973, 92-94.

Denyer, J. "Student Expectations and Needs," AUCC Proc. 1973, 124-29.

Filion, G. "Ce que le public pense des étudiants," AUCC Proc. 1973, 95-97.

Gordon, A. "Accessibility and Equal Opportunity," AUCC Proc. 1973, 103-09.

B Political and Social Involvement / Engagement politique et sociale

Axelrod, P. "Patterns of Student Politics," Univ. Affairs XIV, 8 (October 1973), 4-5. Ghaem-Maghami, F. "Political Climates, Political Knowledge and Political Preferences of University Students," Alta. Jour. Ed. Res. XIX, 1 (March 1973), 22-9.

C Financial Aid / Aide financière

Boucher, J. "Aide financière aux étudiants et problèmes financiers des étudiants," AUCC Délibérations 1973, 110-13.

D Housing / Logement

Rannells, C. and J. Southin. "Trends in University Residences," Univ. Affairs XIV, 9 (November 1973), 12-13.

E Counselling and Guidance / Orientation

Hudson, R.I. "Canadian University Counselling Services," Univ. Affairs XIII, 2 (February 1972), 12-13.

F Placement/Emploi

Canada, Department of Manpower and Immigration. Career Outlook, University and Community College: Arts and Science, 1972-73. Ottawa: Information Canada, 1973. Pp. 41.

Canada, Department of Manpower and Immigration. Career Outlook, University and Community College: Environmental Sciences and Studies, 1972-73. Ottawa: Information Canada, 1973. Pp. 34.

Canada, Department of Manpower and Immigration. Career Outlook, University and Com- 
munity College: Fine Arts and Communications, 1972-73. Ottawa: Information Canada, 1973. Pp. 41.

Canada, Department of Manpower and Immigration. Career Outlook, University and Community College: Health and Health Services, 1972-73. Ottawa: Information Canada, 1973. Pp. 31.

\section{G External Organizations / Organisations extérieures}

Woodcock, L. "New Union Exorcising Ghost of CUS," Univ. Affairs XIV, 8 (October, 1973), 2.

\section{The Professor and Conditions of Work / Le Professeur et les conditions de travail}

\section{A General/Généralités}

Boiven, N. "The Academic Woman and the Canadian University," Univ. Affairs XIV, 6 (July 1973), 2-3.

Braybrooke, D. "Tenure-Illusion and Reality," Univ. Affairs XIII, 4 (April 1972), 3.

Brazeau, J. "Syndicalisation chez les professeurs: quelques causes et certaines conséquences," Univ. Affairs XIV; 9 (November 1973), 5-6.

Daly, J. "Academic Liberalism and the Canadian Identity Question," Univ. Affairs XIV, 5 (May 1973), 6-7.

"Directives concernant la charge de travail confiée aux professeurs," CAUT Bull. XXI, 4 (March 1973), 25-26.

"The First Co-ordinating Board? Bill 105 - An Act to Provide for Collective Bargaining for Crown Employees," OCUFA Newsletter VI, 1 (October 1972), 1-2.

Griffiths, N. "National Affiliations of Faculty: Dispassionate Discussions Difficult," Univ. Affairs XIII, 10 (December 1972), 4.

"Guidelines Concerning Faculty Workload," CAUT Bull. XXI, 4 (March 1973), 23-24.

"Guidelines Concerning the Patent Policies of Universities," CAUT Bull. XXI, 3 (January 1973), 27-28.

"The Istvan Meszaros Case and York University-the University Reports," Univ. Affairs XIV, 1 (January 1973), 8.

Mallock, A. "Tenure-Safeguard not Freehold," Univ. Affairs XIII, 4 (April 1972), 2.

Margeson, J. "Hidden Forces Transform Activist U.S. Professors into Quiet Canadians," OCUFA Newsletter VI, 4 (April 1973), 11.

Monahan, A. "Collective Bargaining-the Issue for the 70's," Univ. Affairs XIII, 9 (November 1972), 10.

"Non-Canadian Faculty: Response of the Moir Committee," Univ. Affairs XIII, 10 (December 1972), 5 .

Page, R. "Canada, Canadian Studies, and . . . the Identity that is," Univ. Affairs XIII, 10 (December 1972), 2-3.

Pommez, M.-C. "La syndicalisation des professeurs d'université: suggestions et mises en garde," CAUT Bull. XXI, 5 (April 1973), 18-23.

Pommez, M.-C. "Tour d'horizon-les syndicats des professeurs," Univ. Affairs XIV, 7 (September 1973), 5.

Proulx, P.-P. "La syndicalisation et ses effets en milieu universitaire," Univ. Affairs XIII, 2 (February 1972), 2-3.

"Tenure-The Government and British Columbia Universities," Univ. Affairs XIII, 4 (April 1972), 4-5.

Trotter, B., L. McQueen and B.L. Hansen, "The Ten O'Clock Scholar? What a Professor Does for his Pay," CAUT Bull. XXI, 3 (January 1973), 4-10.

Wood, S. "Tenure-Do Professors Need Lifetime Job Security?" Univ. Affairs XIII, 4 (April 1972), 5-6. 
Wyman, M. "Tenure Granting Procedures: How Good are They?" Univ. Affairs XIII, 7 (September 1972), 3-4.

B Professor as Teacher

Hedley, R.L. and C.C. Wood. "Improving University Teaching," Univ. Affairs XIV, 4 (April 1973), 2-3.

D Salary and Benefits / Salaires et bénéfices

Friedman, K.A. "Collective Bargining in Calgary?" CAUT Bull. XXI, 4 (March 1973), 1415.

Harrington, W.E. "Report on a Survey of Librarians' Vacation, Study Leave and Other Conditions of Work," CACUL Newsletter IV, 7 (April 1973), 694-99.

Savage, D.C. "Professional Societies and Trade Unions: the Canadian Experience in Higher Education," CAUT Bull. XXI, 4 (March 1973), 4-5.

\section{II - NON-DEGREE GRANTING INSTITUTIONS ETABLISSEMENTS QUI NE CONFERENT PAS DE GRADE}

\section{General/Généralités}

Canada, Statistics Canada, Education, Science and Culture Division. Education in Canada: $a$ Statistical Review for the Period 1960-61 to 1970-71. Ottawa: Information Canada, 1973. Pp. 613.

\section{Quebec/Québec}

Asselin, P.-P. "Le Collège Saguenay-Lac Saint-Jean: un modèle en voie de réalisation," Prospectives VIII, 5 (décembre, 1972), 395-400.

Bielinsky, E. "Les services aux étudiants dans les CEGEP: comment ils sont organisés," Educ. Québec I, 1 (septembre 1970), 17-22; 2 (septembre 1970), 3-8.

Coisman, N. "Enseignement professionnel: enseignement dominé?" Prospectives IX, 5 (décembre 1973), 274-83.

Daignault, A. "Les limites et les prétentions du plan d'études," Prospectives IX, 5 (décembre 1973), 284-89.

Denis, A. et J. Lipkin, "Le CEGEP: promesse et réalité," Prospectives IX, 1 (février 1973), 14-23.

Direction générale de l'enseignement collégial. "La régionalisation des CEGEP," Prospectives VIII, 5 (décembre 1972), 347-54.

Farine, A. "Demographic and Social Accounting: a Follow-up on the Withdrawals from Quebec colleges," Can. Admin. XIII, 4 (January 1974), 19-22.

Gagné, F. "La recherche pédagogique au niveau collégial," Act. Péd. 15 (juin 1970), 39-61.

Gariépy, W. "La documentation québécoise traitant de la régionalisation de l'enseignement collégial," Prospectives VIII, 5 (décembre 1972), 355-58.

Lamontagne, J., C.B. Parizeau et R. Therrien. "Le test PERPE et les valeurs éducatives des professeurs de CEGEP," Prospectives IX, 5 (décembre 1973), 290-99.

LeBlanc, A.E. "La coopération entre les collèges anglophones," Perspectives VIII, 5 (décembre 1972), 365-71.

Maheu, R. "La clientèle de niveau collégial par régions," Perspectives VIII, 5 (décembre 1972), 380-93. 


\section{Ontario}

Dupre, J.S. et al. Federalism and Policy Development: the Case of Adult Occupational Training in Ontario. Toronto: U. of T. Press, 1973. Pp. 264.

\section{Saskatchewan}

Minister's Advisory Committee on Community Colleges. Report of . . . Saskatchewan: Department of Continuing Education, 1972. Pp. 64. 